\title{
Analisis Pemahaman Konsep pada Materi Perubahan Wujud Zat dengan Menggunakan Instrumen Three Tier Test Siswa SMA Negeri 1 Lore Utara
}

\author{
Analysis of Concept Understanding on Material Changes in Substance Forms by Using \\ Three Tier Test Instruments for Students of SMA Negeri 1 Lore Utara
}

\author{
R. E. Saputra*, M. Pasaribu, dan Syamsu \\ Program Studi Pendidikan Fisika FKIP Universitas Tadulako \\ *e-mail: ikyeko21@gmail.com
}

\begin{tabular}{l}
\hline Article Info \\
\hline Article History: \\
Received: 26 October 2021 \\
Accepted: 31 October 2021 \\
Published: 3 November 2021 \\
Keywords: \\
pemahaman konsep, \\
three tier test, \\
perubahan wujud zat \\
\end{tabular}

\begin{abstract}
This study aims to describe the understanding of students at SMA Negeri 1 Lore Utara on the concept of changing the state of matter. Subjects and respondents in this study were 29 students of SMA Negeri 1 Lore Utara. The research instrument used was a concept understanding test in the form of multiple choice reasoned accompanied by a level of confidence in answering questions (tree tier test). The test instrument used was 25 number of questions. The test result data is then analyzed to determine the percentage of understanding scientific concepts, misconceptions, and not understanding concepts. Based on the results of the research data analysis, the percentage of the category not understanding the concept of $44.28 \%$, understanding scientific concepts $16.97 \%$, and misconceptions of $38.76 \%$. From the results of the study, it can be concluded that the understanding of the concept of changing the state of matter in the students of SMA Negeri 1 Lore Utara is still very low.
\end{abstract}

\section{PENDAHULUAN}

Fisika merupakan suatu ilmu yang sangat berhubungan erat dengan fenomena alam. Sebagai suatu ilmu maka tentu fisika memiliki berbagai macam konsep. Menurut Dahar (dalam ref. [1]) konsep merupakan suatu dasar untuk berpikir dan melakukan proses-proses mental yang lebih tinggi agar dapat merumuskan prinsip-prinsip dan generalisasi-generalisasi. Pemahaman konsep sangat berarti dan penting sebagai suatu cara untuk mengorganisir atau menyusun pengetahuan dan merupakan dasar untuk membangun pemikiran menuju pada tingkat yang lebih tinggi [1].

Pembelajaran fisika di sekolah hendaknya mendukung adanya perubahan konsepsi (conceptual change). Menurut Berg (dalam ref. [1]) bahwa inti pengetahuan fisika adalah mencakup konsep-konsep. Dalam belajar fisika, kemampuan pemahaman konsep dasar secara benar merupakan syarat yang mutlak untuk mencapai keberhasilan dalam belajar fisika [1].

Rendahnya pemahaman konsep ilmiah masih menjadi salah satu masalah dalam suatu pembelajaran di sekolah. Para peneliti menemukan berbagai hal yang menjadi penyebab rendahnya pemahaman konsep. Secara garis besar, disebabkan karena siswa, guru, buku teks, konteks, dan metode mengajar. Penyebab yang berasal dari siswa dapat berupa prakonsepsi, tahap perkembangan, minat dan cara berpikir. Penyebab yang berasal dari guru berupa ketidakmampuan guru dalam mengajar, kurangnya penguasaan bahan pelajaran, atau sikap guru yang berelasi dengan siswa kurang baik. Penyebab dari buku teks dapat berupa penjelasan atau uraian yang salah dalam buku tersebut. Sedangkan metode mengajar yang hanya menekankan kebenaran dari satu segi sering memunculkan salah pengertian pada siswa [2].

Hasil belajar adalah kemampuan yang dimiliki siswa setelah menerima pengalaman belajar. Salah satu penilaian hasil belajar adalah penilaian kognitif yang dilakukan setelah siswa mempelajari suatu kompetensi dasar dan jenjang satuan pendidikan. Menurut Supartini dan Djamarah menyebutkan bahwa rendahnya prestasi belajar yang diperoleh dari proses pembelajaran dikarenakan siswa mengalami kesulitan belajar [3].

Kesulitan belajar yang dialami siswa perlu diatasi agar siswa tidak mengalami kesulitan dalam memahami konsep 
fisika selanjutnya. Cara mengatasi kesulitan belajar siswa adalah dengan melakukan analisis kesulitan belajar siswa. Analisis kesulitan belajar siswa dapat dilakukan melalui penilaian, penilain yang dilakukan harus bersifat diagnostik agar dapat diketahui kelemahan-kelemahan siswa sehingga berdasarkan kelemahan tersebut dapat dilakukan pemberian penanganan yang tepat. Persoalan yang sering muncul adalah ketika guru akan mengupayakan pengobatannya, namun guru mengalami permasalahan dalam membedakan antara siswa yang memamahi konsep dengan baik, tidak tahu konsep (kurang pengetahuan) atau siswa yang miskonsepsi [4].

Salah satu bentuk soal yang dapat digunakan untuk melakukan diagnostik adalah three tier test. Three tier test yaitu soal pilihan ganda dengan tiga tingkat pertanyaan dimana tingkat pertama menanyakan materi, tingkat kedua menanyakan alasan dari jawaban tingkat pertama, dan tingkat ketiga berupa indeks keyakinan siswa dalam menjawab. Kelebihan dari instrumen three tier test adalah dapat mengidentifikasi pemahaman konsep peserta didik dengan mudah dan tidak membutuhkan banyak waktu, dapat mengetahui kemungkinan peserta didik yang menjawab salah karena mengalami miskonsepsi atau tidak memahami materi [5].

Salah satu konsep fisika yang erat kaitannya dengan kehidupan siswa dan siswa sering mengalami miskonsepsi adalah konsep suhu dan kalor. Beberapa penelitian menemukan bahwa siswa berpendapat suhu dan kalor adalah hal yang sama, suhu suatu benda bergantung pada besar atau massa dimana bila benda besar maka suhunya pun besar, suhu benda terus meningkat saat mengalami perubahan wujud [2], dan jika massa kecil maka kalor yang akan diserap lebih besar sehingga suhunya cepat naik dan jika kapasitas kalor besar maka suhu benda akan cepat naik [6].

Tujuan penelitian ini adalah untuk mendeskripsikan pemahaman siswa di SMA Negeri 1 Lore Utara terhadap konsep perubahan wujud zat.

\section{METODE PENELITIAN}

Penelitian ini merupakan penelitian kualitatif yang datanya berupa fakta-fakta yang ada, sehingga dalam penelitian ini digunakan pendekatan deskriptif kualitatif. Responden dalam penelitian ini berjumlah 29 orang. Responden tersebut diberikan tes pemahaman konsep berbentuk pilihan ganda beralasan yang disertai dengan tingkat keyakinannya (tree tier test) untuk mengetahui tingkat pemahaman siswa terhadap konsep perubahan wujud zat.

Analisis data yang digunakan pada penelitian ini berdasarkan pada jawaban siswa dari tes yang diberikan. Alasan dan tingkat keyakinan yang diberikan oleh siswa dianalisis dan disesuaikan dengan pilihan jawaban yang dipilih untuk menentukan konsepsi yang dimiliki oleh siswa.

Pedoman interpretasi dalam three tier test dibuat dalam bentuk tabel yang berisi dua bagian yaitu kolom kategori interpretasi dan kolom tipe respons. Pada kolom tipe respons terbagi menjadi tiga bagian yaitu kolom jawaban, kolom alasan, dan kolom tingkat keyakinan seperti yang ditunjukkan oleh Tabel 1 [7].

Tabel 1. Interpretasi Hasil Three Tier Test

\begin{tabular}{lccc}
\hline \multirow{2}{*}{ Kategori } & \multicolumn{3}{c}{ Tipe Respons } \\
\cline { 2 - 4 } Memahami & Jawaban & Alasan & Keyakinan \\
& benar & benar & yakin \\
\multirow{2}{*}{ Tidak } & benar & salah & tidak yakin \\
Memahami & salah & benar & tidak yakin \\
& salah & salah & tidak yakin \\
& salah & salah & yakin \\
Miskonsepsi & salah & benar & yakin \\
& benar & salah & yakin \\
\hline
\end{tabular}

Data yang diperoleh dari jawaban akan dipersentasekan dan dianalisis menggunakan statistik sederhana yaitu menyajikan persentase pemahaman konsep mahasiswa untuk setiap item. Untuk menentukan persentase berdasarkan setiap option digunakan persamaan:

$$
A=\frac{x}{n} \times 100 \%
$$

Keterangan:

$A \quad$ :persentase pemilihan setiap option

$x \quad$ :jumlah mahasiswa yang memilih option

$n$ :banyaknya peserta tes

Setelah itu dilakukan perhitungan rata-rata pemahaman konsep, selanjutnya persentase pemahaman konsep atau paham konsep ilmiah dikualifikasikan seperti pada Tabel 2 [8].

Tabel 2. Persentase Kualifikasi Pemahaman Konsep

\begin{tabular}{cc}
\hline Persentase(\%) & $\begin{array}{c}\text { Kualifikasi Pemahaman } \\
\text { Konsep }\end{array}$ \\
\hline $81-100$ & Sangat tinggi \\
$61-80,99$ & Tinggi \\
$41-60,99$ & Cukup \\
$21-40,99$ & Rendah \\
$0-20,99$ & Sangat rendah \\
\hline
\end{tabular}

\section{HASIL DAN PEMBAHASAN}

\section{Hasil Penelitian}

Hasil penelitian menunjukkan pemahaman konsep mahasiswa dalam memahami konsep perubahan wujud zat seperti pada Tabel 3 . 
Tabel 3. Persentase Pemahaman Konsep Perubahan Wujud Zat

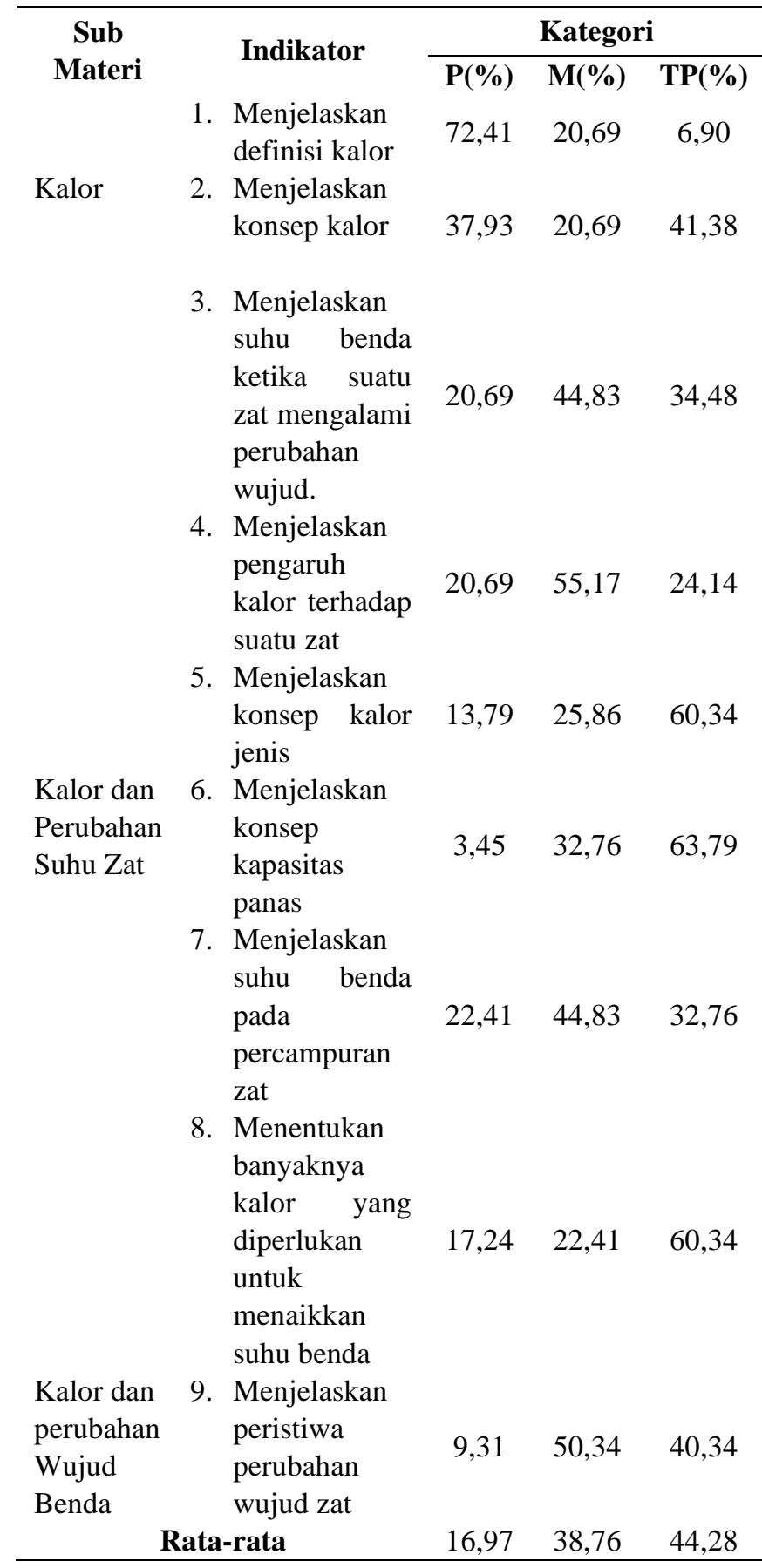

\section{Keterangan: \\ P : Paham Konsep \\ TP : Tidak Paham Konsep \\ M : Miskonsepsi}

\section{Pembahasan}

Sub Materi Kalor. Sub materi kalor terdiri atas dua indikator, yaitu indikator 1 dan indikator 2 .

Indikator 1 adalah menjelaskan pengertian kalor yaitu energi yang berpindah karena adanya perbedaan suhu.
Indikator 1 terdapat pada soal nomor 1. Hasil analisis jawaban responden pada indikator 1 , diperoleh persentase siswa yang paham konsep sebesar 72,41\%, miskonsepsi sebesar 20,69\%, dan tidak paham konsep sebesar 6,90\%. Pada indikator ini responden memahami suatu konsep yang tidak tepat karena belum dapat membedakan antara besaran-besaran pada kalor dan cara perpindahannya.

Indikator 2 adalah menjelaskan konsep kalor yaitu benda dengan suhu lebih tinggi cenderung melepaskan kalor dan benda dengan suhu lebih rendah cenderung menyerap kalor yang mana benda melepaskan kalor akan mengalami penurunan suhu dan benda yang menyerap kalor akan mengalami peningkatan suhu. Indikator 2 terdapat pada soal nomor 2 dan 3. Hasil analisis jawaban responden pada indikator 2, diperoleh persentase siswa yang paham konsep rata-rata sebesar 37,93\%, miskonsepsi rata-rata sebesar $20,69 \%$, dan tidak paham konsep rata-rata sebesar $41,38 \%$. Pada indikator ini responden cenderung tidak konsisten menjawab ataupun kurang memahami bahwa benda dengan suhu lebih tinggi cenderung melepaskan kalor sebaliknya benda dengan suhu lebih rendah cenderung menerima kalor serta kurang memahami tentang hubungan antara kalor dan suhu adalah berbanding lurus sehingga banyak responden yang kurang tepat dalam menjawabnya.

Sub Materi Kalor dan Perubahan Suhu Zat. Sub materi kalor dan perubahan suhu zat terdiri atas enam indikator, yaitu indikator 3, indikator 4, indikator 5, indikator 6, indikator 7, dan indikator 8 .

Indikator 3 adalah menjelaskan suhu benda ketika suatu zat mengalami perubahan wujud dalam hal ini ketika zat berada pada kesetimbangan termal, kemudian zat itu dipisahkan maka suhu masing-masing tetap sama dengan suhu awalnya. Indikator 3 terdapat pada soal nomor 4. Hasil analisis jawaban responden pada indikator 3, diperoleh persentase siswa yang paham konsep sebesar 20,69\%, miskonsepsi sebesar $44,83 \%$, dan tidak paham konsep sebesar $34,48 \%$. Pada indikator ini miskonsepsi terjadi karena responden beranggapan bahwa ukuran benda mempengaruhi suhunya dan kurang memahami bahwa ketika pada kesetimbangan termal, kemudian benda itu dipisahkan maka suhu masingmasing tetap sama dengan suhu awalnya.

Indikator 4 adalah menjelaskan pengaruh kalor terhadap suatu zat yaitu penyerapan kalor akan merubah wujud, suhu dan massa jenis suatu zat. Indikator 4 terdapat pada soal nomor 5. Hasil analisis jawaban responden pada indikator 4, diperoleh persentase siswa yang paham konsep konsep sebesar 20,69\%, miskonsepsi sebesar 55,17\%, dan tidak paham konsep sebesar 24,14\%. Pada indikator ini miskonsepsi terjadi karena responden beranggapan bahwa massa jenis tidak berubah ketika benda tersebut menerima kalor. Ketika benda tersebut menyerap kalor maka jarak antar partikel tersebut akan semakin jauh ataupun volumenya mengembang sehingga masa jenisnya akan berubah. Penyerapan kalor juga akan mempengaruhi suhu dan wujud benda tersebut.

Indikator 5 adalah menjelaskan konsep kalor jenis yaitu kalor jenis bergantung pada jenis benda, benda dengan kalor 
jenis akan akan memerlukan banyak kalor untuk kenaikkan suhunya, dan zat dengan kalor jenis tinggi dapat dimanfaatkan sebagai penghangat ruangan karena memiliki banyak energi panas. Indikator 5 terdapat pada soal nomor 6, 7, 8, dan 9 . Hasil analisis jawaban responden pada indikator 5, diperoleh persentase siswa yang paham konsep rata-rata sebesar $13,79 \%$, miskonsepsi rata-rata sebesar $25,86 \%$, dan tidak paham konsep rata-rata sebesar $60,34 \%$. Pada soal nomor 6 responden terjebak pada persamaan banyaknya kalor yang diperlukan untuk menaikkan suhu zat yaitu hasil kali antara massa, kalor jenis dan kenaikan suhu sehingga responden berpikir kalor jenis benda akan bergantung pada besarnya kalor, massa dan perubahan suhunya. Pada soal nomor 7 responden masih banyak mengalami kesalahpahaman dengan menganggap kalor jenis berbanding lurus dengan suhu sehingga semakin besar kalor jenis maka semakin cepat benda tersebut untuk melebur dan membeku yang mana seharusnya semakin besar kalor jenis maka semakin lama mengalami kenaikkan suhu. Pada soal nomor 8 responden kurang memahami bahwa zat dengan kalor jenis tinggi akan menyerap lebih banyak kalor untuk kenaikkan suhunya sehingga pertambahan suhunya akan kecil. Pada soal nomor 9 responden belum mampu memahami bahwa zat dengan kalor jenis yang tinggi dapat dimanfaatkan sebagai penghangat ruangan karena dapat membawa banyak kalor pada proses transfer kalor.

Indikator 6 adalah menjelaskan konsep kapasitas kalor yaitu kapasitas kalor berbanding lurus dengan massa dan kalor jenis, kapasitas kalor berbanding terbalik dengan perubahan suhu. Indikator 6 terdapat pada soal nomor 10 dan 11. Hasil analisis jawaban responden pada indikator 6, diperoleh persentase siswa yang paham konsep rata-rata sebesar $3,45 \%$, miskonsepsi rata-rata sebesar $32,76 \%$, dan tidak paham konsep rata-rata sebesar $63,79 \%$. Pada indikator ini, banyak responden yang salah paham mengenai penyimbolan antara kapasitas panas dan kalor jenis serta masih banyak responden yang salah paham dan terbalik dalam menentukan perbandingan suhu akibat perbedaan kapasitas kalor yang disajikan dalam soal.

Indikator 7 adalah menjelaskan suhu benda pada percampuran zat yaitu suhu pada percampuran zat akan berada pada suhu setimbang dimana benda dengan suhu lebih tinggi akan melepaskan kalor dan benda dengan suhu lebih rendah akan menyerap kalor. Indikator 7 terdapat pada soal nomor 12 dan 13. Hasil analisis jawaban responden pada indikator 7, diperoleh persentase siswa yang paham konsep sebesar 22,41\%, miskonsepsi rata-rata sebesar 44,83\%, dan tidak paham konsep rata-rata sebesar $32,76 \%$. Pada indikator ini banyak responden yang salah paham dalam membedakan benda yang menerima kalor dan benda yang melepaskan kalor sehingga kesulitan dalam menetukan suhu campurannya serta masih banyak responden yang belum memahami akibat penyerapan dan pelepasan kalor terhadap suhu suatu zat.

Indikator 8 adalah menentukan banyaknya kalor yang diperlukan untuk menaikkan suhu benda yaitusebanding dengan massa, kalor jenis dan perubahan suhunya. Indikator 8 terdapat pada soal nomor 14 dan 15 . Hasil analisis jawaban responden pada indikator 8 , diperoleh persentase siswa yang paham konsep sebesar $17,24 \%$, miskonsepsi rata-rata sebesar $22,41 \%$, dan tidak paham konsep rata-rata sebesar $60,34 \%$. Miskonsepsi pada soal nomor 14 terjadi karena responden kurang mencermati dengan baik persamaan besarnya kalor yang digunakan untuk menaikkan suhu sehingga keliru dalam melakukan perhitungan. Miskonsepsi pada nomor 15 terjadi karena responden beranggapan agar suhu air menjadi 3T, maka hal yang dapat dilakukan adalah massa diperbesar 3 kali dan kalor diperkecil 1/3Q dengan alasan massa berbanding lurus dengan suhu, kalor berbanding terbalik dengan suhu.

Sub Materi Kalor dan Perubahan Wujud Benda. Sub materi kalor dan perubahan wujud benda terdiri atas satu indikator, yaitu indikator 9 yang terdapat pada soal nomor 16 , 17, 18, 19, 20, 21, 22, 23, 24, dan 25. Paham konsep ilmiah tertinggi pada soal nomor 16. Miskonsepsi tertinggi berada pada soal nomor 22. Sedangkan tidak paham konsep tertinggi terdapat pada soal nomor 21 .

Indikator 9 adalah menjelaskan peristiwa perubahan wujud zat yaitu menerangkan tentang pengaruh penyerapan dan pelepasan kalor terhadap wujud benda. Hasil analisis jawaban responden pada indikator 9 , diperoleh persentase siswa yang paham konsep rata-rata sebesar 9,31\%, miskonsepsi sebesar $50,34 \%$, dan tidak paham konsep sebesar 40,34\%. Pada indikator ini responden belum mampu memahami akibat pelepasan dan penyerapan kalor ada peristiwa perubahan wujud, kurang memahami bahwa penyerapan kalor pada titik didih suatu zat digunakan untuk mengubah wujud dari zat tersebut, responden tidak bisa membedakan antara kalor yang diperlukan untuk mengubah suhu zat dan kalor yang digunakan untuk mengubah wujud zat, kurang memahami bahwa ciri dari perubahan wujud yang memerlukan kalor yaitu terjadinya peningkatan suhu, dan kurang memahami bahwa ketika air telah mencapai titik uap jenuh maka suhu tidak bias naik lagi sehingga pada saat memasak ubi perlu menurunkan suhunya dengan cara mengecilkan apinya.

Berdasarkan hasil analisis ketiga sub materi yaitu kalor, kalor dan perubahan suhu zat, serta kalor dan perubahan wujud benda, pemahaman konsep tertinggi terdapat pada sub materi kalor. Sedangkan pemahaman konsep terendah terdapat pada sub materi kalor dan perubahan wujud benda. Rata-rata pemahaman konsep siswa SMA Negeri 1 Lore Utara yaitu $16,97 \%$. Persentase pemahaman konsep siswa tersebut masih termasuk dalam kategori sangat rendah, kategori ini dapat dilihat pada Tabel 2 .

\section{KESIMPULAN}

Berdasarkan hasil analisis data penelitian, disimpulkan bahwa pemahaman konsep perubahan wujud zat pada siswa SMA Negeri 1 Lore Utara masih sangat rendah. Pada penelitian ini secara umum diperoleh persentase kategori tidak paham konsep sebesar 44,28\%, paham konsep ilmiah sebesar $16,97 \%$, dan miskonsepsi sebesar 38,76\%. Adapun persentase pada sub materi kalor diperoleh persentase kategori tidak paham konsep sebesar 24,14\%, paham konsep ilmiah sebesar 
$55,17 \%$, dan miskonsepsi sebesar 20,69\%. Pada sub materi kalor dan perubahan suhu zat diperoleh persentase kategori tidak paham konsep sebesar 45,98\%, paham konsep ilmiah sebesar $16,38 \%$, dan miskonsepsi sebesar 37,64\%. Pada sub materi kalor dan perubahan wujud zat diperoleh persentase kategori tidak paham konsep sebesar 40,34\%, paham konsep ilmiah sebesar 9,31\%, dan miskonsepsi sebesar 50,34\%\%.

\section{SARAN}

Bagi peneliti berikutnya diharapkan dapat melakukan penelitian lebih lanjut tentang pemahaman konsep materi perubahan wujud zat pada siswa. Penelitian berikutnya diharapkan dapat mengungkap bagaimana cara meremediasi miskonsepsi dan meningkatkan penguasaan konsep fisika menjadi lebih baik.

\section{REFERENSI}

[1] W. Rusli \& A. Haris, "Studi Miskonsepsi Peserta Didik Kelas IX SMP Negeri 1 Makassar pada Pokok Bahasan Gerak dan Gaya", Jurnal Sains dan Pendidikan Fisika, 12(2), 192-199, 2016.

[2] P. Suparno, "Miskonsepsi dan Perubahan Konsep dalam Pendidikan Fisika", Jakarta : PT Grasindo, 2013.

[3] Suwarto, "Pengembangan Tes Diagnostik dalam Pembelajaran”, Yogyakarta : Pustaka Belajar, 2013.

[4] N. Maunah, "Pengembangan Two-Tier Multiple Choice Diagnostic Test untuk Menganalisis Kesulitan Belajar Siswa Kelas X pada Materi Suhu dan Kalor", Inovasi Pendidikan Fisika, 3(2), 2014.

[5] S. A. S. Daud, "Identifikasi Pemahaman Konsep Perubahan Wujud Zat dengan Menggunakan Instrumen Tes Tiga Tingkat (Three-Tier Test) pada Siswa Kelas VII MTs Negeri Model Limboto", Jurnal Penelitian Tahun 2014, 2014.

[6] D. Hafizah., V. Haris \& E. Eliwatis, "Analisis Miskonsepsi Siswa Melalui Tes Multiple Choice Menggunakan Certainty Of Response Index pada Mata Pelajaran Fisika Man 1 Bukittinggi”, Jurnal Pendidikan MIPA Edusainstika, 1(1). 2014.

[7] S. L. Handayani., A. Rusilowati \& Sugianto, "Mengembangkan Tes Diagnostik Pilihan Ganda Tiga Tingkat Sebagai Evaluasi Miskonsepsi Materi Optik", Seminar Nasional Evaluasi Pendidikan Tahun 2014, 2014.

[8] I. Zulkarnain, "Model Penemuan Terbimbing dengan Teknik Mind Mapping Untuk Meningkatkan Kemampuan
Pemahaman Konsep Matematis Siswa SMP", Jurnal Pendidikan Matematika, 2(3), pp. 240 - 249, 2014. 